\title{
Anti-Oxidative Effect of Weak Alkaline Reduced Water in RAW 264.7 Murine Macrophage Cells
}

\author{
Thuy Thi Trinh ${ }^{1,2}$, Ailyn Fadriquela ${ }^{3}\left(\mathbb{D}\right.$, Johny Bajgai ${ }^{1}\left(\mathbb{D}\right.$, Subham Sharma ${ }^{1,2}$, Md. Habibur Rahman ${ }^{1,2}{ }^{(\mathbb{D}}$, \\ Seong-Hoon Goh ${ }^{1}$, Song-Sik Khang ${ }^{4}$, Woo-Rham Khang ${ }^{4}$, Cheol-Su Kim ${ }^{1}{ }^{1}$ and Kyu-Jae Lee ${ }^{1, *}$ \\ 1 Department of Environmental Medical Biology, Wonju College of Medicine, Yonsei University, \\ Wonju 26426, Korea; tththuy@hpmu.edu.vn (T.T.T.); johnybajgai@yonsei.ac.kr (J.B.); \\ 2020323346@yonsei.ac.kr (S.S.); pharmacisthabib@yonsei.ac.kr (M.H.R.); forget419@yonsei.ac.kr (S.-H.G.); \\ cs-kim@yonsei.ac.kr (C.-S.K.) \\ 2 Department of Global Medical Science, Wonju College of Medicine, Yonsei University, Wonju 26426, Korea \\ 3 Department of Laboratory Medicine, Wonju College of Medicine, Yonsei University, Wonju 26426, Korea; \\ ailyn@yonsei.ac.kr \\ 4 Hanumul Co., Ltd., Ilsan Dong-gu, Goyang-si 10442, Korea; han4804@hanumul.co.kr (S.-S.K.); \\ cittuhand@hanumul.co.kr (W.-R.K.) \\ * Correspondence: medbio@yonsei.ac.kr; Tel.: +82-337410331; Fax: +82-337316953
}

check for

Citation: Trinh, T.T.; Fadriquela, A.; Bajgai, J.; Sharma, S.; Rahman, M.H.; Goh, S.-H.; Khang, S.-S.; Khang,

W.-R.; Kim, C.-S.; Lee, K.-J.

Anti-Oxidative Effect of Weak Alkaline Reduced Water in RAW 264.7 Murine Macrophage Cells. Processes 2021, 9, 2062. https:// doi.org/10.3390/pr9112062

Academic Editor: Grzegorz Bartosz

Received: 26 October 2021

Accepted: 12 November 2021

Published: 18 November 2021

Publisher's Note: MDPI stays neutral with regard to jurisdictional claims in published maps and institutional affiliations.

Copyright: (c) 2021 by the authors. Licensee MDPI, Basel, Switzerland. This article is an open access article distributed under the terms and conditions of the Creative Commons Attribution (CC BY) license (https:// creativecommons.org/licenses/by/ $4.0 /)$.

\begin{abstract}
Excessive oxidative stress (OS) is a common cause of various diseases such as cancer, diabetes, and obesity; thus, an anti-oxidative solution is essential for the improvement of human health. Increasing evidence suggests that alkaline reduced water (ARW), especially between $\mathrm{pH}$ 9.5-10.0, has antioxidant capacity; however, relatively few studies have reported the effect of weak ARW at pH 8.5 on OS, especially in vitro. This study was conducted to evaluate the anti-oxidative efficacy of weak ARW with negative oxidation-reduction potential (ORP) and relatively high hydrogen $\left(\mathrm{H}_{2}\right)$ concentration, as compared to tap water (TW) and ARW at pH 9.5. RAW 264.7 murine macrophage cells, stimulated by hydrogen peroxide $\left(\mathrm{H}_{2} \mathrm{O}_{2}\right)$ and lipopolysaccharide (LPS) to induce OS, were used as a control (Con) and then treated with TW and ARW at pH 8.5 (ARW_8.5) and pH 9.5 (ARW_9.5) at different concentrations $(0.1 \%, 1 \%$, and $10 \% v / v)$. Results showed that cell viability was significantly restored after treatment with both ARW_8.5 and ARW_9.5 compared to Con/ $\mathrm{H}_{2} \mathrm{O}_{2}$ and Con/LPS, while TW treatment did not induce significant changes. Levels of reactive oxygen species (ROS), nitric oxide (NO), $\mathrm{Ca}^{2+}$, catalase, and glutathione peroxide (GPx) showed significant differences in a concentration-dependent manner in ARW_8.5 and ARW_9.5 groups compared to Con $/ \mathrm{H}_{2} \mathrm{O}_{2}$ and Con/LPS groups. Likewise, the expression of p-p38, p-JNK, and p-ERK was also significantly reduced in the ARW-treated groups, but not in the TW group. In conclusion, ARW_8.5 exhibited anti-oxidative effects through the regulation of the MAPK signaling pathway in RAW 264.7 murine macrophage cells, indicating the health-promoting potential of weak ARW through daily intake.
\end{abstract}

Keywords: alkaline reduced water; anti-oxidative effect; RAW 264.7; MAPK

\section{Introduction}

Alkaline reduced water (ARW) is produced by a water-electrolyzed pool at a cathode plate [1]. It is known by numerous names such as alkaline ionized water, alkaline electrolyzed water, or electrolyzed reduced water, and it is becoming increasingly popular worldwide, especially in Southeast Asian countries [2,3]. Water serves as a construction material, a solvent, a reaction medium, a reactant, a carrier of nutrients and waste, a thermoregulator, a lubricant, and a shock absorber in the human body [4,5]. A sedentary adult needs to consume $1.5 \mathrm{~L}$ of water each day on an average [4]. Moreover, the Environmental Protection Agency (EPA) suggested that the $\mathrm{pH}$ of drinking water should be between 6.5 and 8.5 [6]. Recently, the use of ARW to improve health has gathered great interest. Previous studies have shown that ARW at $\mathrm{pH} 9.5$ reduces the levels of free 
radicals, promotes antioxidant levels, prevents reactive oxygen species (ROS)-induced DNA damage, and promotes health through the reduction of oxidative stress (OS) [7-10]. Additionally, several in vivo studies and clinical trials have shown the anti-allergy, antidiabetic [11], anti-hangover [3] and anti-aging [12] effects of ARW at $\mathrm{pH}>9$. Moreover, a recent clinical study showed that ARW consumption reduced OS, increased antioxidant potential, and decreased fat mass [13]. Interestingly, to address the debate on the long-term effects of drinking ARW, Magro et al. reported that mice were given alkaline ionized water to drink showed a longer lifespan than control mice watered with tap water (TW) in a 3-year survival study [8]. This evidence suggests the efficacy of ARW in treating OS-related diseases.

OS is defined as an imbalance in the body's levels of free radicals and antioxidants, as well as a disruption in the generation and buildup of reactive oxygen species (ROS) in cells and tissues, as well as biological systems' ability to purify these products [14]. Lipopolysaccharide (LPS) and hydrogen peroxide $\left(\mathrm{H}_{2} \mathrm{O}_{2}\right)$ stimulate the increase in ROS levels and induce OS, which may be mediated through the mitogen-activated protein kinase (MAPK) signaling pathway in murine macrophage cell lines [15,16]. RAW 264.7 cells are monocyte/macrophage-like cells generated from an Abelson leukemia virus-transformed $\mathrm{BALB} / \mathrm{c}$ mouse cell line. These cells have been considered a suitable macrophage type as evidence found that the phenotype and functional characteristics of RAW 264.7 remained stable through passages [17], and these cells mimic bone-marrow derived macrophages, which initiate cellular activation and responses to microorganisms and their products $[18,19]$. ROS plays a protective as well as destructive role; the overproduction of ROS can lead to the dysregulation of nitric oxide (NO) and intracellular calcium $\left(\mathrm{Ca}^{2+}\right)$, resulting in deleterious effects and damage to cellular structures in the body [20]. The consumption of antioxidant products is considered a preferred solution; therefore, various studies have been conducted on the use of products with high antioxidant activity, such as alkaline compounds, hydrogen $\left(\mathrm{H}_{2}\right)$ and electrolyzed reduced water [21-23].

In Japan, an electrolyzing device for generating ARW was created and approved as a household medical device use after safety and efficacy testing. The Japanese Ministry of Health, Labor, and Welfare recommends a pH of 9.5 for drinking ARW, with a pH limit of not more than 10. In Korea, the Ministry of Food and Drug Safety also approved the alkaline water-generating device as a household medical device (grade II) and stipulated a $\mathrm{pH}$ range of 8.5-10.0 for ARW. ARW is characterized by parameters such as negative oxidationreduction potential (ORP), $\mathrm{H}_{2}$ concentration, and $\mathrm{pH}$, and the parameters proportionately affect each other under different conditions such as the strength of electric current and mineral concentration during electrolysis. With this, users can choose the degree of $\mathrm{pH}$ using buttons or dials that are set on the device. Owing to the functionality of alkaline properties, studies related to safety and efficacy have mainly focused on the high $\mathrm{pH}$ of ARW; consequently, the efficacy and mechanism of weak ARW have been rarely studied. Currently, ARW-generating devices are widely used to replace water purifiers. Given that people drink large amounts of water throughout their lives, it is necessary to understand the effect of ARW at different $\mathrm{pH}$ values. Thus, the purpose of this research was to explore

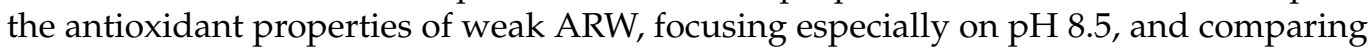
it with the efficacy of weak ARW at pH 9.5 in RAW 264.7 monocyte/macrophage cell line. Furthermore, we assessed the potential mechanism by which weak ARW exerts an anti-oxidative effect by measuring MAPK-related protein expression.

\section{Materials and Methods}

\subsection{Reagents and Antibodies}

Cytiva Hyclone provided Dulbecco's Modified Eagle Medium (DMEM) (South Logan, UT, USA). GibcoTM (Invitrogen, Carlsbad, CA, USA) supplied the penicillin/streptomycin (antibiotic) solution, and Hyclone Laboratories, Inc. gave the fetal bovine serum (FBS) (South Logan, UT, USA). Sigma-Aldrich contributed to the lipopolysaccharide (LPS, serotype O111:B4) (Gillingham, UK). Daejung produced 30 percent of the $\mathrm{H}_{2} \mathrm{O}_{2}$ (Siheung-si, Gyeonggi- 
do, Korea). Quanti-MaxTM (BIOMAX Co., Seoul, Korea) furnished the Cell Counting Kit-8 (CCK-8) and Sigma-Aldrich Inc. offered the 2'7'-dicholodihydrofluorescin diacetate (DCFH-DA) reagent (St. Louis, MO, USA). iNtRON Biotechnology (Sungnam, South Korea) supplied the NO reagent (Griess reagent kit), while BioVision Inc. supplied the catalase assay kit, glutathione peroxidase (GPx) assay kit, and calcium $\left(\mathrm{Ca}^{2+}\right)$ colorimetric test kit (Milpitas, CA, USA). Takara Bio Inc. provided the Takara BCA Protein Assay Kit (Kusatsu, Japan). Rabbit monoclonal IgM antibodies recognizing phospho-p38 (p-p38), phospho-c-Jun N-terminal kinase (p-JNK), phospho-extracellular signal-related kinase (p-ERK), and $\beta$-actin (dilution 1:2000) were used as primary antibodies, and horseradish peroxidase-linked anti-rabbit IgG obtained from Cell Signaling Technology (Danvers, MA, USA) was applied as the secondary antibody (dilution 1:5000).

Characteristics of Alkaline Reduced Water

ARW was produced by using an ARW generating device (EP-5001, Hanumul Co., Ltd., Goyang-si, Republic of Korea), which is equipped with a dual electrolysis system, and TW was used as control. To confirm the properties of the experimental water samples (TW, ARW at pH 8.5 [ARW_8.5], and ARW at pH 9.5 [ARW_9.5]), pH (HM-31P, TOA DKK, Tokyo, Japan), ORP (RM-30P, TOA DKK, Tokyo, Japan), TDS (BOMEX, Beijing, China), and $\mathrm{H}_{2}$ (MARK-509, Dissolved Hydrogen Meter, Nizhny Novgorod, Russia) were measured, and the results are shown in Table 1.

Table 1. Major water physical and chemical components of tap water and alkaline reduced water.

\begin{tabular}{cccc}
\hline & TW & ARW_8.5 & ARW_9.5 \\
\hline $\mathrm{pH}$ & 7.7 & 8.5 & 9.5 \\
$\mathrm{ORP}(\mathrm{mV})$ & 609 & -63 & -394 \\
$\mathrm{H}_{2}(\mathrm{ppb})$ & 0 & 150 & 225 \\
$\mathrm{TDS}(\mathrm{mg} / \mathrm{L})$ & 63 & 67 & 73 \\
\hline $\mathrm{Ca}^{2+}(\mathrm{mg} / \mathrm{L})$ & 19.96 & 21.23 & 26.88 \\
$\mathrm{~K}^{+}(\mathrm{mg} / \mathrm{L})$ & 2.39 & 2.55 & 2.70 \\
$\mathrm{Mg}^{2+}(\mathrm{mg} / \mathrm{L})$ & 3.66 & 3.43 & 3.87 \\
$\mathrm{Na}^{+}(\mathrm{mg} / \mathrm{L})$ & 6.92 & 7.22 & 7.39 \\
$\mathrm{Cl}^{-}(\mathrm{mg} / \mathrm{L})$ & 13 & 12 & 9 \\
Residual chlorine & 0.9 & $\mathrm{ND}$ & $\mathrm{ND}$
\end{tabular}

The water quality analysis was commissioned by a specialized agency in Korea (Korea Environment \& Water Works Institute). ORP, oxidation-reduction potential; TDS, total dissolved solids; $\mathrm{H}_{2}$, hydrogen molecules. TW, tap water; ARW, alkaline reduced water. ARW was produced by using ARW generating device (EP-5001, Hanumul Co., Ltd., Goyang-si, Korea).

\subsection{Experimental Design}

RAW 264.7 murine macrophage cells were thawed and sub-cultured following specific groups for 5 days. For the induction of OS, cells were exposed to $200 \mu \mathrm{mol} / \mathrm{mL} \mathrm{H}_{2} \mathrm{O}_{2}$ for $2 \mathrm{~h}$ and $10 \mu \mathrm{g} / \mathrm{mL}$ LPS for $24 \mathrm{~h}$ before treatment with TW, ARW_8.5, and ARW_9.5 for $24 \mathrm{~h}$ (HAN-ICH2000, Hanumul Co., Ltd., Goyang-si, Korea). On day 7 of the experiment, the cells were collected, and cell viability, ROS, NO, antioxidant enzyme activities (GPx and catalase), and intracellular $\mathrm{Ca}^{2+}$ levels were measured. Additionally, MAPK signaling pathway-related proteins such as p-p38, p-JNK, and p-ERK were evaluated by western blotting.

\subsection{Cell Culture and LPS Stimulation}

RAW 264.7 macrophage cells (American Type Cell Culture Collection, Rockville, MD, USA) were cultivated in DMEM with $10 \%$ FBS and $1 \%$ antibiotic in $75 \mathrm{~mm}$ flasks at $37^{\circ} \mathrm{C}$ with $5 \% \mathrm{CO}_{2}$ in a humidified atmosphere to determine the optimal concentration and time for LPS stimulation. In these investigations, RAW 264.7 cells were seeded at a density of $5 \times 10^{3}$ cells per well. The cells were treated with different concentrations of LPS $(0.4,2$, 
and $10 \mu \mathrm{g} / \mathrm{mL}$ ) for $6,12,24$, and $48 \mathrm{~h}$ after achieving 80 percent confluence. Cell viability was evaluated using the CCK-8 test kit according to the manufacturer's instructions.

\subsection{Cell Culture and $\mathrm{H}_{2} \mathrm{O}_{2}$ Stimulation}

RAW 264.7 macrophage cells (American Type Cell Culture Collection, Rockville, MD, USA) were cultivated in DMEM with $10 \%$ FBS and $1 \%$ antibiotic in $75 \mathrm{~mm}$ flasks at $37{ }^{\circ} \mathrm{C}$ with $5 \% \mathrm{CO}_{2}$ in a humidified atmosphere to determine the optimal concentration and time for $\mathrm{H}_{2} \mathrm{O}_{2}$ stimulation. In these investigations, RAW 264.7 cells $\left(5 \times 10^{3}\right.$ cells per well) were performed. The cells were treated with 50,100, and $200 \mu \mathrm{mol} / \mathrm{mL} \mathrm{H}_{2} \mathrm{O}_{2}$ for 30, 60, 90, and 120 min after achieving 80 percent confluence. Following the manufacturer's instructions, the CCK-8 test kit was used to assess cell viability.

\subsection{Cell Proliferation Assay}

RAW 264.7 macrophage cells were planted with a density of $1 \times 10^{4}$ cells per well in a 96-well plate and incubated for $24 \mathrm{~h}$ at $37{ }^{\circ} \mathrm{C}$ in $5 \% \mathrm{CO}_{2}$. The cells were treated with $\mathrm{H}_{2} \mathrm{O}_{2}$ or LPS for the indicated periods and concentrations. After being washed twice with 1X PBS, the CCK-8 test kit was used to assess cell proliferation, and the manufacturer's protocol was followed.

\subsection{Analysis of OS Marker Levels}

Following the manufacturer's instructions, ROS levels were identified by the DCFHDA reagent. Before being treated with $\mathrm{H}_{2} \mathrm{O}_{2}$ or LPS for the indicated periods and concentrations, RAW 264.7 cells were plated in 96-well black plates $\left(1 \times 10^{4}\right.$ cells per well). After that, the cells were treated by ARW following indicated concentrations and time. The cells were then rinsed twice with 1 X PBS before being replaced with a mixture of $20 \mu \mathrm{L}$ of lysis buffer and $30 \mu \mathrm{L}$ of $1 \mathrm{X}$ PBS. After that, $100 \mu \mathrm{L}$ of $10 \mu \mathrm{M}$ DCFH-DA was added to each well, and the plate was incubated at $37^{\circ} \mathrm{C}$ for $30 \mathrm{~min}$. The fluorescence was measured at $488 \mathrm{~nm}$ excitation/525 nm emission using a DTX multi-mode microplate reader (Beckman Coulter Inc., Brea, CA, USA).

Following the manufacturer's instructions, NO levels were assessed using the Griess reagent (iNtRON). Before the cells were treated with $\mathrm{H}_{2} \mathrm{O}_{2}$ or LPS, the cells were plated in 96-well plates $\left(1 \times 10^{4}\right.$ cells per well). After that, the cells were treated by ARW following indicated concentrations and time. The cells were then rinsed twice with $1 X$ PBS before being replaced with a mixture of $20 \mu \mathrm{L}$ of lysis buffer and $30 \mu \mathrm{L}$ of 1 X PBS. Finally, cells were exposed to Griess reagent and incubated at room temperature (RT) (20-22 $\left.{ }^{\circ} \mathrm{C}\right)$ for $15 \mathrm{~min}$, as per the manufacturer's procedure. Spectra-Max ${ }^{\circledR}$ ABS Plus was used to measure the absorbance at $540 \mathrm{~nm}$ (Molecular Devices, San Jose, CA, USA).

\subsection{Analysis of Antioxidant Enzyme Activities}

BioVision kit (BioVision, Inc., Milpitas, CA, USA) was used to assess the intracellular levels of endogenous antioxidant enzymes (catalase and GPx) according to the manufacturer's instructions. Cell lysates collected from 6-well plate cell seeding $\left(0.2 \times 10^{6}\right.$ cells per well) were centrifuged at $10,000 \mathrm{rpm}$ for $15 \mathrm{~min}$ at $4^{\circ} \mathrm{C}$. According to the manufacturer's instructions, the cell supernatant was assayed to measure catalase and GPx activities. In a 96-well microplate, $50 \mu \mathrm{L}$ of samples for the catalase test and $50 \mu \mathrm{L}$ of samples for the GPx assay were added, and the plates were incubated for $30 \mathrm{~min}$. A SpectraMax ${ }^{\circledR}$ ABS Plus was used to detect the optical densities of catalase at $570 \mathrm{~nm}$ and GPx at $340 \mathrm{~nm}$ (Molecular Devices, San Jose, CA, USA). Both enzyme activities were measured in nanomoles per milliliter (nmol/mL).

\section{8. $\mathrm{Ca}^{2+}$ Assay}

Following the manufacturer's instructions, intracellular $\mathrm{Ca}^{2+}$ levels were determined using a $\mathrm{Ca}^{2+}$ colorimetric assay kit (Bio-Vision, Mountain View, CA, USA). Cell lysates, which were collected from 6 -well plate cell seeding $\left(0.2 \times 10^{4}\right.$ cells per well), were prepared 
with $\mathrm{Ca}^{2+}$ assay buffer and centrifuged at $10,000 \mathrm{rpm}$ for $10 \mathrm{~min}$ at $4{ }^{\circ} \mathrm{C}$. The supernatant was collected to assess intracellular $\mathrm{Ca}^{2+}$ levels. Briefly, $50 \mu \mathrm{L}$ of samples were placed in a 96-well microplate, which was then incubated for $30 \mathrm{~min}$. Using a Spectra-Max ${ }^{\circledR}$ ABS Plus, the optical density of each well was measured at $590 \mathrm{~nm}$ (Molecular Devices, San Jose, CA, USA). The results were given in milligrams per deciliter $(\mathrm{mg} / \mathrm{dL})$.

\subsection{Western Blot Analysis}

The cell supernatant, which was normalized protein concentrations, was loaded equally and separated on a sodium dodecyl sulfate-polyacrylamide gel electrophoresis before being electrophoretically transferred onto polyvinylidene difluoride membranes (Sartorius, Bohemia, NY, USA). The membrane was then blocked for $2 \mathrm{~h}$ at room temperature with protein-free blocking buffer (Takara Bio Inc., Kusatsu, Japan) before being incubated overnight at $4{ }^{\circ} \mathrm{C}$ with the primary anti-bodies p-p38, p-JNK, p-ERK, and $\beta$-actin (dilution: 1:2000; Cell Signaling Technology, Inc., Danvers, MA, USA) in Tris-buffered saline/Tween 20 (1X TBST) containing 5\% bovine. The membrane was then incubated for $2 \mathrm{~h}$ at RT with a horseradish peroxidase-conjugated anti-rabbit secondary antibody (dilution 1:2000; Cell Signaling Technology). An enhanced chemiluminescence kit (ECL Pierce Biotechnology) UVP Bio Spectrum 600 Imaging System was used to detect bound antibodies (UVP, LLC, Upland, CA, USA). As a loading control for total protein content, $\beta$-actin (dilution 1: 2000, Cell Signaling Technology, Inc., Danvers, MA, USA ) was utilized. ImageJ was used to examine band intensity (Version 150-win Java, USA).

\subsection{Data Management and Statistical Analysis}

The mean \pm standard error of the mean was used to depict data (SEM). All data were normalized, and fold changes were calculated relative to the normal control. Two-way analysis of variance (ANOVA) was used to examine and compare the data, followed by a multiple comparison test using the GraphPad Prism 8.0 software package (GraphPad, La Jolla, CA, USA). Statistical significance was defined as a difference of $p<0.05$.

\section{Results}

3.1. Effect of Alkaline Reduced Water on Cell Viability in $\mathrm{H}_{2} \mathrm{O}_{2}$ - and Lipopolysaccharide-Induced RAW 264.7 Murine Macrophage Cells

The viability of cells treated with $\mathrm{H}_{2} \mathrm{O}_{2}$ and LPS was significantly decreased (both $p<0.001$ ) compared to the normal control group. However, cells treated with ARW_8.5 showed a similar increase in cell viability as those treated with ARW_9.5, which was not observed in TW-treated cells. Upon treatment of ARW, the cell viability of the ARW_9.5 group was significantly increased at $0.1 \%(p<0.001$ and $p<0.001), 1 \%(p<0.001$ and $p<0.001)$, and $10 \%(p<0.001$ and $p<0.001)$ compared to that of Con $/ \mathrm{H}_{2} \mathrm{O}_{2}$ and Con/LPS groups. Moreover, the cell viability of the ARW_8.5 group was significantly increased at $0.1 \%(p<0.05$ and $p<0.05), 1 \%(p<0.01$ and $p<0.001)$, and $10 \%(p<0.01$ and $p<0.001)$ compared to that of Con $/ \mathrm{H}_{2} \mathrm{O}_{2}$ and Con/LPS groups. However, cells treated with TW did not show any significant change in viability compared to Con $/ \mathrm{H}_{2} \mathrm{O}_{2}$ and Con/LPS groups (Figure 1).

\subsection{Effect of Alkaline Reduced Water on OS Production in $\mathrm{H}_{2} \mathrm{O}_{2}$ - and Lipopolysaccharide- Induced RAW 264.7 Murine Macrophage Cells}

The cells treated with ARW_8.5 showed a similar increase in the reduction of OS production as those treated with ARW_9.5. ROS and $\mathrm{NO}$ levels of $\mathrm{Con} / \mathrm{H}_{2} \mathrm{O}_{2}$ and Con/LPS groups were significantly increased compared to those of the normal control group $(p<0.001)$ (Figure 2). After treatment with ARW, ROS levels were dramatically decreased by $1 \%(p<0.01)$ and $10 \%(p<0.001)$ in ARW_8.5 and ARW_9.5 groups compared to those in the Con $/ \mathrm{H}_{2} \mathrm{O}_{2}$ group. However, ROS levels were significantly increased in the TW group at $1 \%(p<0.05)$ and $10 \%(p<0.01)$ (Figure 2A). With LPS induction, ROS levels were significantly decreased in the ARW_9.5 group at $0.1 \%(p<0.001), 1 \%(p<0.001)$, and $10 \%(p<0.001)$ compared to those in the Con/LPS group. Similarly, ROS levels were signif- 
icantly decreased in the ARW 8.5 group at $1 \%(p<0.001)$ and $10 \%(p<0.001)$ compared to those in the Con/LPS group (Figure 2B). Levels of NO were significantly decreased in a concentration-dependent manner in the ARW_9.5 group at $0.1 \%(p<0.001$ and $p<0.01), 1 \%$ $(p<0.001$ and $p<0.001)$, and $10 \%(p<0.001$ and $p<0.001)$ compared to those in Con $/ \mathrm{H}_{2} \mathrm{O}_{2}$ and Con/LPS groups. Similarly, NO levels were significantly decreased in the ARW_8.5 group at $0.1 \%(p<0.05$ and $\mathrm{p}<0.01), 1 \%(p<0.001$ and $p<0.001)$, and $10 \%(p<0.001$ and $p<0.001$ ) compared to those in Con $/ \mathrm{H}_{2} \mathrm{O}_{2}$ and Con/LPS groups (Figure $2 \mathrm{C}, \mathrm{D}$ ).

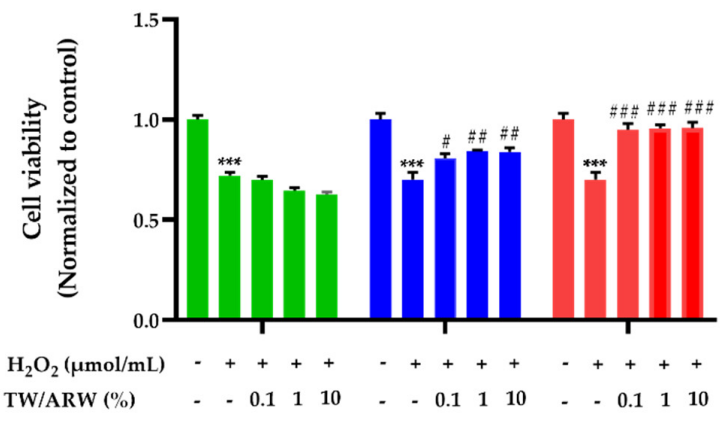

(A)

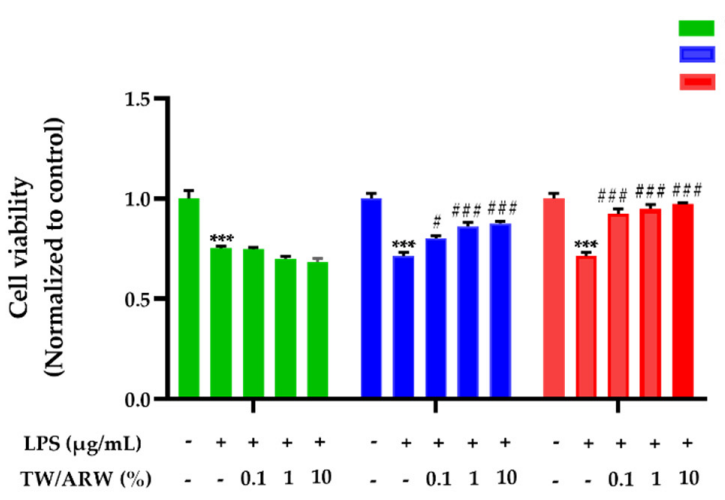

(B)

Figure 1. Effect of ARW_8.5 and ARW_9.5 on cell viability in $\mathrm{H}_{2} \mathrm{O}_{2}$ - and LPS-induced RAW 264.7 murine macrophage cells. Cell toxicity was induced by $\mathrm{H}_{2} \mathrm{O}_{2}(200 \mu \mathrm{mol} / \mathrm{mL}$ for $2 \mathrm{~h})(\mathbf{A})$ and LPS $(10 \mu \mathrm{g} / \mathrm{mL}$ for $24 \mathrm{~h})(\mathbf{B})$, and cells were treated with ARW (pH 8.5 and $\mathrm{pH} 9.5$ ) at concentrations of $0.1 \%, 1 \%$, and $10 \%$. Data are expressed as the mean \pm standard error of the mean (SEM) of the fold change relative to the control $(n=3)$. Statistical significance was analyzed with two-way ANOVA. TW: tap water, (-): non-treatment, (+): treatment. ${ }^{* * *}, p<0.001$ vs. normal control; ${ }^{\#}, p<0.05$; ${ }^{\#}, p<0.01$, and \#\#\#, $p<0.001$ vs. Con $/ \mathrm{H}_{2} \mathrm{O}_{2}$ or Con/LPS. Abbreviations: Con, control; ARW, alkaline reduced water; $\mathrm{TW}$, tap water; $\mathrm{H}_{2} \mathrm{O}_{2}$, hydrogen peroxide; LPS, lipopolysaccharide.

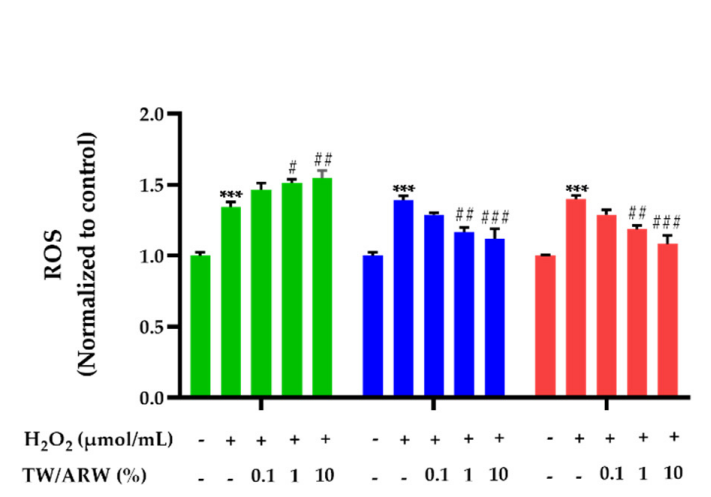

(A)

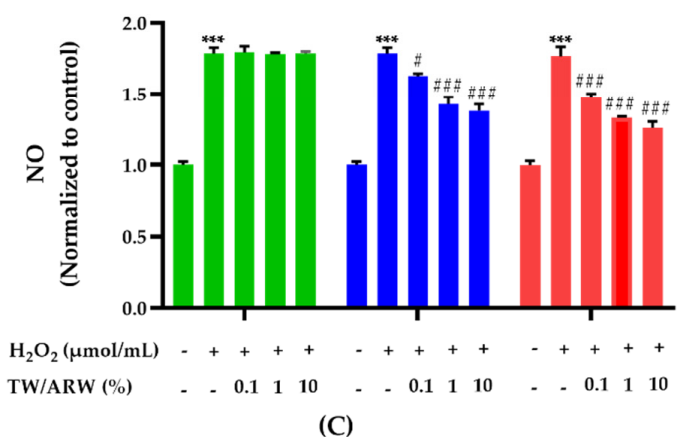

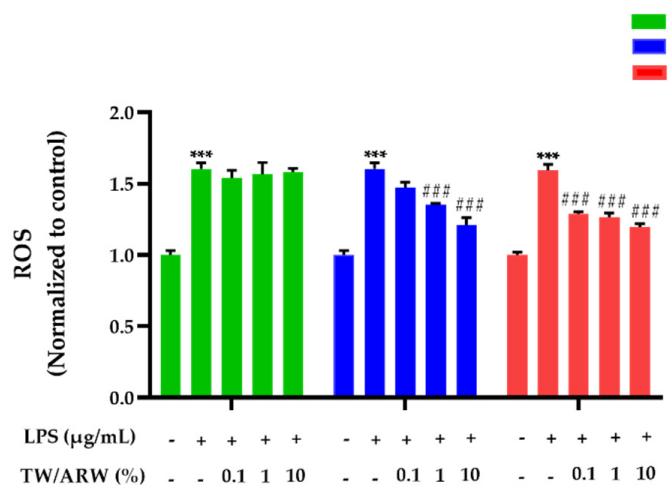

(B)

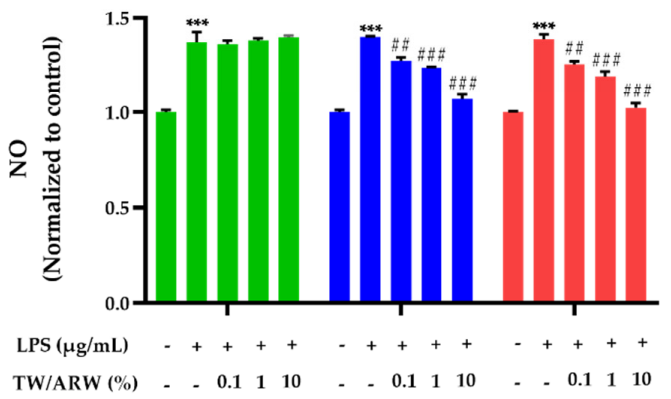

(D)

Figure 2. Effect of ARW_8.5 and ARW_9.5 on the level of ROS and NO in $\mathrm{H}_{2} \mathrm{O}_{2}-$ and LPS-induced RAW 264.7 murine macrophage cells. The levels of ROS and NO were induced by $\mathrm{H}_{2} \mathrm{O}_{2}(200 \mu \mathrm{mol} / \mathrm{mL}$ for $2 \mathrm{~h})(\mathbf{A}, \mathbf{C})$ and LPS $(10 \mu \mathrm{g} / \mathrm{mL}$ for 
$24 \mathrm{~h}$ ) (B,D), and the cells were treated with ARW (pH 8.5 and $\mathrm{pH} 9.5$ ) at concentrations of $0.1 \%, 1 \%$, and $10 \%$. Data are expressed as the mean \pm standard error of the mean (SEM) of the fold change relative to the control $(n=3)$. Statistical significance was analyzed with two-way ANOVA. (-): non-treatment, $(+)$ : treatment. ${ }^{* * *}, p<0.001$ vs. normal control. $\#, p<0.05 ;{ }^{\#}, p<0.01$, and ${ }^{\# \#}, p<0.001$ vs. Con $/ \mathrm{H}_{2} \mathrm{O}_{2}$ or Con/LPS. Abbreviations: ARW, alkaline reduced water; TW, tap water; $\mathrm{H}_{2} \mathrm{O}_{2}$, hydrogen peroxide; LPS, lipopolysaccharide; ROS, reactive oxygen species; $\mathrm{NO}$, nitric oxide; Con, control.

\subsection{Effect of Alkaline Reduced Water on GPx and Catalase Activity in $\mathrm{H}_{2} \mathrm{O}_{2}-$ and Lipopolysaccharide-Induced RAW 264.7 Murine Macrophage Cells}

Stimulation of cells with $\mathrm{H}_{2} \mathrm{O}_{2}$ and LPS induced a significant decrease in GPx activity and an increase in catalase activity (both $p<0.001$ ). However, the activities showed significant differences after treatment with ARW in a concentration-dependent manner, while there was no difference in the TW treatment group. Moreover, both ARW groups showed a similar trend in the activity of GPx and catalase (Figure 3). The activity of GPx was significantly increased after treatment of cells with ARW_9.5 at $0.1 \%(p<0.05$ and $p<0.01), 1 \%(p<0.001$ and $p<0.01)$, and $10 \%(p<0.001$ and $p<0.01)$ compared to that in Con $/ \mathrm{H}_{2} \mathrm{O}_{2}$ and LPS groups. Moreover, the activity of GPx was significantly increased after treatment of cells with ARW_8.5 at $1 \%\left(p<0.05\right.$ vs. Con $\left./ \mathrm{H}_{2} \mathrm{O}_{2}\right)$ and $10 \%(p<0.001$ vs. Con $/ \mathrm{H}_{2} \mathrm{O}_{2}$ and $p<0.001$ vs. Con/LPS) (Figure $\left.3 \mathrm{~A}, \mathrm{~B}\right)$. In contrast, catalase activity in the ARW_9.5 group was significantly decreased at $0.1 \%(p<0.01$ and $p<0.01), 1 \%(p<0.001$ and $p<0.001)$, and $10 \%(p<0.001$ and $p<0.001)$ compared to that in $\mathrm{Con} / \mathrm{H}_{2} \mathrm{O}_{2}$ and Con/LPS groups. Catalase activity in the ARW_8.5 group showed a significant decrease at $1 \%(p<0.01$ and $p<0.05)$ and $10 \%(p<0.01$ and $p<0.001)$, respectively, compared to that in Con $/ \mathrm{H}_{2} \mathrm{O}_{2}$ and Con/LPS groups (Figure 3C,D).

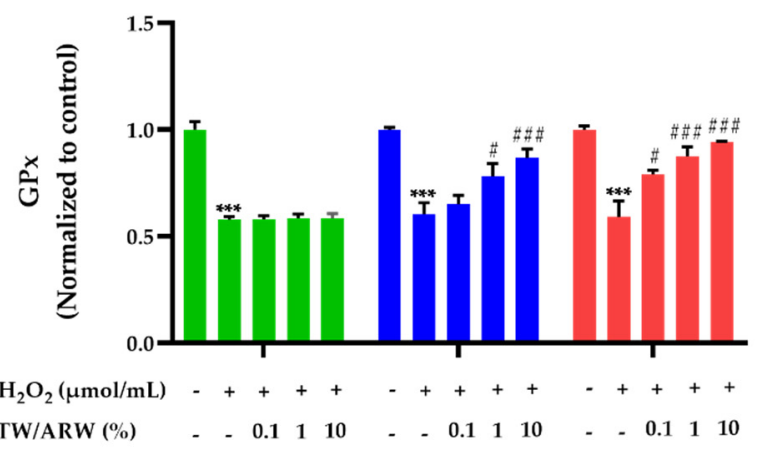

(A)

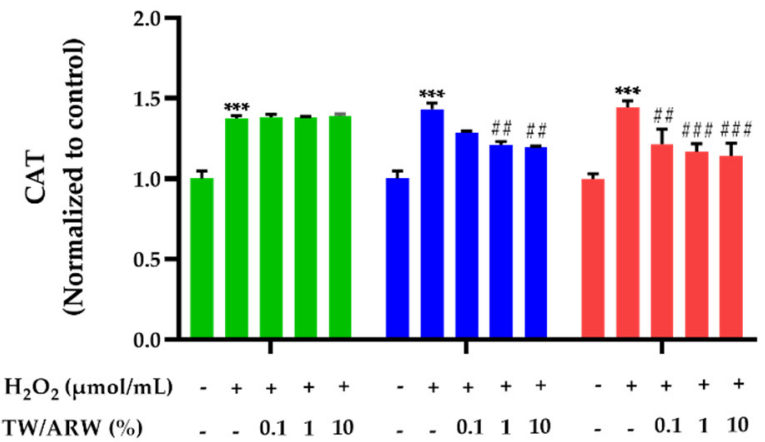

(C)

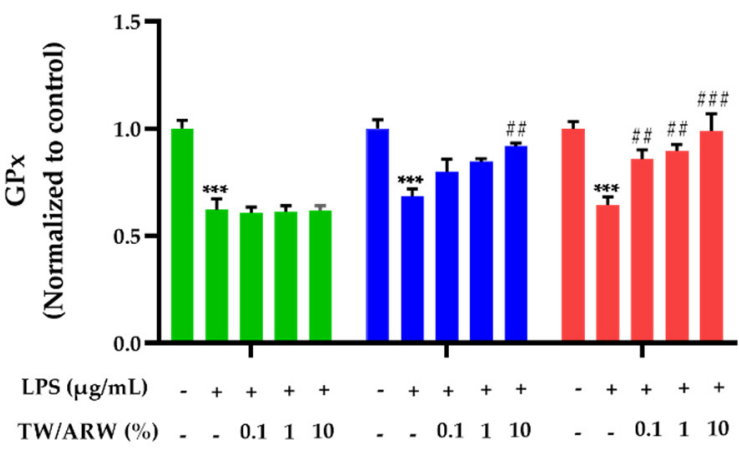

(B)

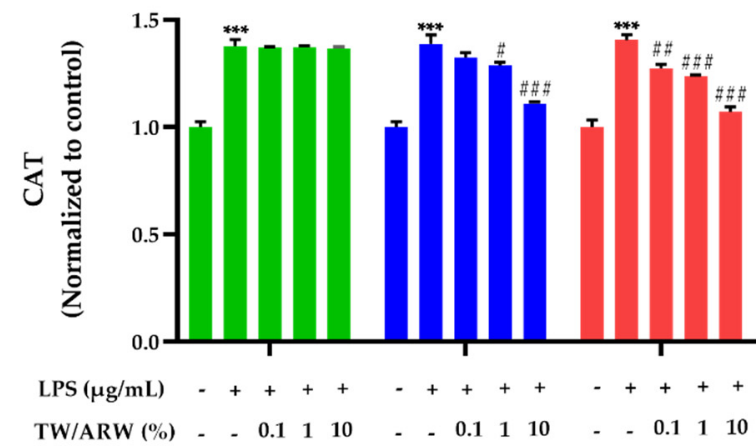

(D)

Figure 3. Effect of ARW at pH 8.5 and pH 9.5 on the activity of antioxidant enzymes (GPx and catalase) in $\mathrm{H}_{2} \mathrm{O}_{2}-$ and LPS-induced RAW 264.7 murine macrophage cells. Cytotoxicity of cells was induced by $\mathrm{H}_{2} \mathrm{O}_{2}(200 \mu \mathrm{mol} / \mathrm{mL}$ for $2 \mathrm{~h})(\mathbf{A}, \mathrm{C})$ and LPS (10 $\mu \mathrm{g} / \mathrm{mL}$ for $24 \mathrm{~h})(\mathbf{B}, \mathbf{D})$, and the cells were treated with ARW (pH 8.5 and $\mathrm{pH} 9.5$ ) at concentrations of $0.1 \%, 1 \%$, 
and $10 \%$. Data are expressed as the mean \pm standard error of the mean (SEM) of the fold change relative to the control $(n=3)$. Statistical significance was analyzed with two-way ANOVA. $(-)$ : non-treatment, $(+)$ : treatment. ${ }^{* *}, p<0.001$ vs. normal control. \#, $p<0.05$; \#\#, $p<0.01$, and ${ }^{\# \#, ~} p<0.001$ vs. Con $/ \mathrm{H}_{2} \mathrm{O}_{2}$ or Con/LPS. Abbreviations: ARW, alkaline reduced water; TW, tap water; $\mathrm{H}_{2} \mathrm{O}_{2}$, hydrogen peroxide; LPS, lipopolysaccharide; GPx, glutathione peroxide; Con, control.

\subsection{Effect of Alkaline Reduced Water on Intracellular $\mathrm{Ca}^{2+}$ Levels in $\mathrm{H}_{2} \mathrm{O}_{2}$ - and Lipopolysaccharide-Induced RAW 264.7 Murine Macrophage Cells}

Intracellular $\mathrm{Ca}^{2+}$ levels were significantly increased in cells treated with $\mathrm{H}_{2} \mathrm{O}_{2}$ and LPS; however, they were decreased in a concentration-dependent manner after treatment of cells with ARW_8.5 and ARW_9.5, with a similar decreasing pattern (Figure 4). Upon treatment with ARW_9.5, $\mathrm{Ca}^{2+}$ levels were significantly decreased at $0.1 \%(p<0.05, p<0.05), 1 \%$ $(p<0.001$ and $p<0.001)$, and 10\% $(p<0.001$ and $p<0.001)$ compared to those in Con $/ \mathrm{H}_{2} \mathrm{O}_{2}$ and Con/LPS groups. Moreover, $\mathrm{Ca}^{2+}$ levels were significantly decreased in the ARW_8.5 group at $1 \%(p<0.01$ and $p<0.01)$ and $10 \%(p<0.001$ and $p<0.001)$ compared to those in the Con $/ \mathrm{H}_{2} \mathrm{O}_{2}$ and Con/LPS groups. However, cells treated with TW did not show any significant change in $\mathrm{Ca}^{2+}$ levels compared to $\mathrm{Con} / \mathrm{H}_{2} \mathrm{O}_{2}$ and Con/LPS groups (Figure 4).

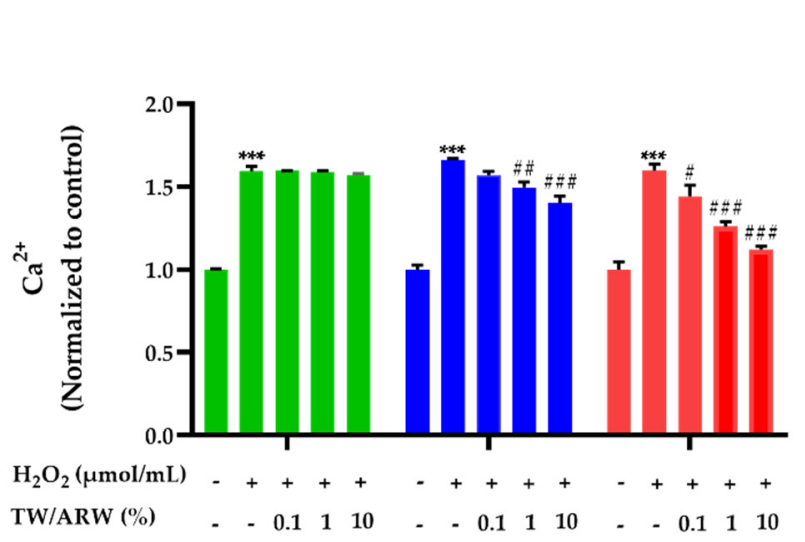

(A)

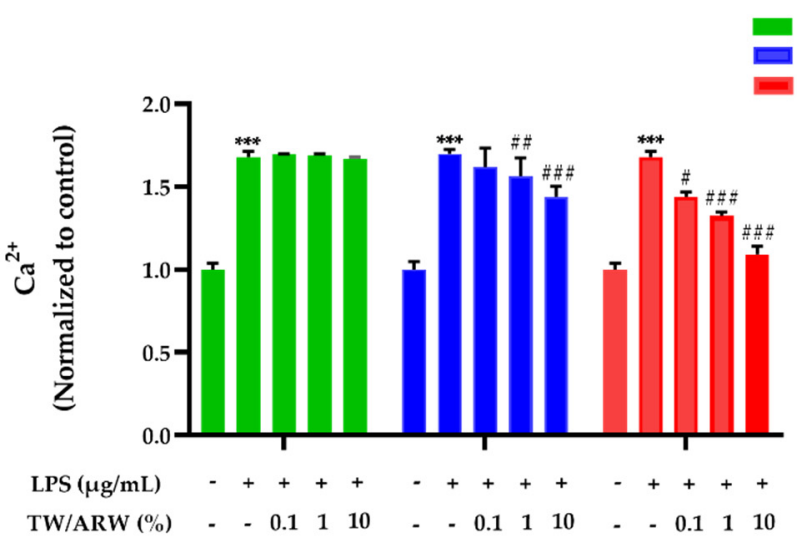

(B)

Figure 4. Effect of ARW_8.5 and ARW_9.5 on intracellular $\mathrm{Ca}^{2+}$ levels in $\mathrm{H}_{2} \mathrm{O}_{2}-$ and LPS-induced RAW 264.7 murine macrophage cells. Cytotoxicity was induced by $\mathrm{H}_{2} \mathrm{O}_{2}(200 \mu \mathrm{mol} / \mathrm{mL}$ for $2 \mathrm{~h})(\mathbf{A})$ and LPS $(10 \mu \mathrm{g} / \mathrm{mL}$ for $24 \mathrm{~h})(\mathbf{B})$, and the cells were treated with ARW ( $\mathrm{pH} 8.5$ and $\mathrm{pH} 9.5$ ) at concentrations of $0.1 \%, 1 \%$, and $10 \%$. Data are expressed as the mean \pm standard error of the mean (SEM) of the fold change relative to the control $(n=3)$. Statistical significance was analyzed with two-way ANOVA. (-): non-treatment, (+): treatment. ${ }^{* * *}, p<0.001$ vs. normal control. ${ }^{\#}, p<0.05$; \#\#, $p<0.01$, and ${ }^{\# \#}, p<0.001$ vs. Con $/ \mathrm{H}_{2} \mathrm{O}_{2}$ or Con/LPS. Abbreviations: ARW, alkaline reduced water; TW, tap water; $\mathrm{H}_{2} \mathrm{O}_{2}$, hydrogen peroxide; LPS, lipopolysaccharide; $\mathrm{Ca}^{2+}$, intracellular calcium; Con, control.

3.5. Effect of Alkaline Reduced Water on p-p38, p-JNK, and p-ERK Expression in $\mathrm{H}_{2} \mathrm{O}_{2}-$ and Lipopolysaccharide-Induced RAW 264.7 Murine Macrophage Cells

The expression of p-p38, p-JNK, and p-ERK was increased significantly after treatment of cells with $\mathrm{H}_{2} \mathrm{O}_{2}$ and LPS compared to that in the normal control group $(p<0.001$, respectively). Upon treatment with ARW_8.5 and ARW_9.5, the expression of p-p38, p-JNK, and p-ERK was significantly decreased in the ARW_8.5-and ARW_9.5 groups compared to the Con $/ \mathrm{H}_{2} \mathrm{O}_{2}$ and Con/LPS groups, respectively. However, the expression levels of p-p38, p-JNK, and p-ERK were lower in the ARW_8.5 group than in the ARW_9.5 group (Figure 5). 

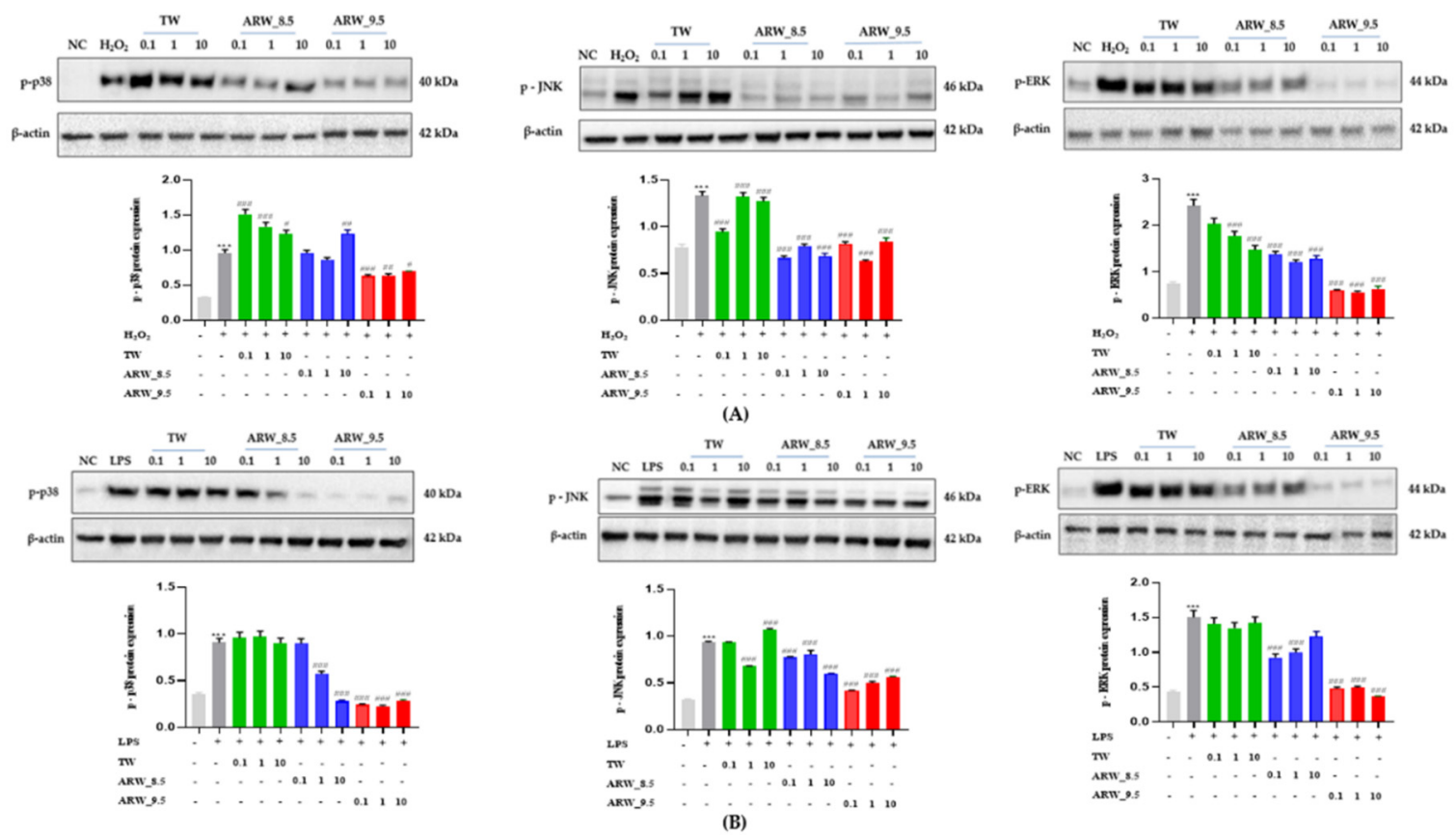

Figure 5. Effect of ARW_8.5 and ARW_9.5 on the expression of MAPK pathway-related proteins (p-p38, p-JNK, and p-ERK) in $\mathrm{H}_{2} \mathrm{O}_{2}$ - and LPS-induced RAW 264.7 murine macrophage cells. Cytotoxicity was induced by $\mathrm{H}_{2} \mathrm{O}_{2}(200 \mu \mathrm{mol} / \mathrm{mL}$ for $2 \mathrm{~h})(\mathbf{A})$ and LPS $(10 \mu \mathrm{g} / \mathrm{mL}$ for $24 \mathrm{~h})(\mathbf{B})$, and the cells were treated with ARW (pH 8.5 and $\mathrm{pH} 9.5)$ at concentrations of $0.1 \%$, $1 \%$, and $10 \%$. Data are expressed as the mean \pm standard error of the mean (SEM) of the fold change relative to the control $(n=3)$. Statistical significance was analyzed with two-way ANOVA. $(-)$ : non-treatment, $(+)$ : treatment. ${ }^{* * *}, p<0.001$ vs. normal control. ${ }^{\prime}, p<0.05$; ${ }^{\#}, p<0.01$, and ${ }^{\# \#, ~}, p<0.001$ vs. Con $/ \mathrm{H}_{2} \mathrm{O}_{2}$ or Con/LPS. Abbreviations: ARW, alkaline reduced water; TW, tap water; $\mathrm{H}_{2} \mathrm{O}_{2}$, hydrogen peroxide; LPS, lipopolysaccharide; MAPK, mitogen-activated protein kinase; p-p38, phospho-p38; (p-JNK), phospho-c-Jun amino-terminal kinases; p-ERK, phospho-extracellular signal-regulated kinases; Con, control.

\section{Discussion}

There has been an increase in not only interest but also skepticism on the use of functional water to improve one's health. While several studies have shown the protective and therapeutic effects of ARW, issues with the continuous use of ARW at high pH still arise. The preference for high $\mathrm{pH}$ is strongly related to the effectiveness of ARW based on accumulated data. In this research, we identified the anti-oxidative effect of weak ARW ( $\mathrm{pH}$ 8.5) compared with TW and ARW_9.5 in RAW 264.7 murine macrophage cells. Moreover, weak ARW is characterized by a higher $\mathrm{H}_{2}$, negative ORP, and alkalinity as compared to TW (Table 1). While most studies used ARW at pH levels of 9.5 to 10.5, relatively few studies have reported the effect of weak ARW, such as ARW at pH 8.5 [3,8,12]. Additionally, to our knowledge, there have been no reports evaluating its effect using an immune macrophage cell line.

Macrophages, which are found in all tissues, are immune cells that play an important role in the defense, homeostasis, and pathogenesis of infectious diseases [24]. Cells of the innate immune system engage in bacterial phagocytosis and secrete both anti-inflammatory and antimicrobial mediators via macrophages. In addition, diseased and damaged cells are eliminated through programmed cell death [25]. Therefore, they are commonly used in in vitro and in vivo assessments of pathophysiological roles in human diseases [26-28]. As mentioned, RAW 264.7 cell line is considered a suitable macrophage type due to its stable phenotype and functional characteristics and is ideal for studying cellular responses [17-19]. Our study first evaluated the effects of weak ARW ( $\mathrm{pH} 8.5$ and $\mathrm{pH} 9.5$ ) on cell viability after induction of $\mathrm{OS}$ by $\mathrm{H}_{2} \mathrm{O}_{2}$ or LPS stimulation. Induction of $\mathrm{H}_{2} \mathrm{O}_{2}$ and LPS reduced cell viability greatly, as expected, but ARW_8.5, like ARW_9.5, dramatically recovered 
$\mathrm{H}_{2} \mathrm{O}_{2}$ - and LPS-induced cell viability when compared to the Con $/ \mathrm{H}_{2} \mathrm{O}_{2}$ and Con/LPS groups. (Figure 2).

In addition, we evaluated ROS and NO generation in $\mathrm{H}_{2} \mathrm{O}_{2}-$ and LPS-induced murine macrophage cell lines following ARW 8.5 treatment to determine the anti-oxidative effect. In reaction to phagocytosis, macrophages generate and release reactive oxygen species (ROS) [29]. However, an excessive increase in ROS levels can activate signaling pathways and can damage DNA, proteins, or lipids [30]. Additionally, dysregulation of $\mathrm{NO}$ production, which causes OS responses in the immune system, is caused by ROS accumulation [30,31]. After $\mathrm{H}_{2} \mathrm{O}_{2}$ and LPS induction, ARW lowered ROS and NO levels in murine macrophage cells in a concentration-dependent manner (Figure 3). Our data showed that ARW_8.5 minimize the excessive production of damaging oxidative stress in the cell. Moreover, weak ARW demonstrated efficacy in boosting antioxidant effects against $\mathrm{H}_{2} \mathrm{O}_{2}$ - and LPS-induced OS, which was compatible to our ROS and NO results, but TW did not. GPx and catalase are antioxidant enzymes that could rescue cells from OS. [32]. In this study, weak ARW mediated the activities of GPx and catalase after $\mathrm{H}_{2} \mathrm{O}_{2}$ and LPS induction, showing its antioxidant capacity (Figure 3). These antioxidants are well known for their role in the decrease of OS effectors such ROS and NO, as well as the antioxidant increase in macrophage cell lines [32,33]. Compared to previous studies on the effects of ARW at $\mathrm{pH}$ ranging from 9.5 to 10.5 , our study on ARW at pH 8.5 confirmed its efficacy in mediating the expression of these OS markers and exerting significant antioxidant effects (Figure 4).

Additionally, to confirm the effectiveness of weak ARW against OS, we assessed intracellular $\mathrm{Ca}^{2+}$ levels. Normally, $\mathrm{Ca}^{2+}$ involves various transport channels and maintains cellular functions [34]. However, $\mathrm{Ca}^{2+}$ overload can stimulate the MAPK signaling pathway and increase ROS and OS responses [35,36]. In the present study, our results showed that ARW_8.5 rescued the cells from the accumulation of high intracellular $\mathrm{Ca}^{2+}$ concentrations (Figure 5). Therefore, our results suggest that similar to ARW_9.5, the long-term intake of weak ARW may reduce ROS and NO generation and can decrease intracellular $\mathrm{Ca}^{2+}$ levels.

Moreover, the current research focused on the MAPK signaling pathway to fully explain the therapeutic mechanism of ARW against $\mathrm{H}_{2} \mathrm{O}_{2}$ - and LPS-induced OS response. The downstream proteins of the MAPK signaling pathway, which is one of three primary pathways involved in early OS and cell viability, are p-p38, p-JNK, and p-ERK. [37]. Furthermore, the results of western blot analysis showed that weak ARW decreased the $\mathrm{H}_{2} \mathrm{O}_{2}$ - and LPS-induced expression of MAPK signaling proteins, including p-p38, p-JNK, and p-ERK (Figure 5). Our results also showed that ARW_8.5 has similar effects as ARW at $\mathrm{pH}$ 9.5, inhibiting the expression of proteins associated with these signaling pathways.

The therapeutic action of weak ARW may be attributed to its higher $\mathrm{H}_{2}$ concentration. Previous studies have reported that $\mathrm{H}_{2}$ is a potential treatment option for OS, and clinical applications of weak ARW has been reported in countries such as Japan, China, Korea, and the USA [38,39]. ORP and alkaline $\mathrm{pH}$ effectiveness have also been evaluated in studies of alkaline electrolyzed water, which also increases antioxidant levels and reduces OS response $[33,40,41]$. The current study, however, has certain limitations. The study simply reported on the anti-oxidative benefits of weak ARW in vitro. Only one macrophage cell line was used (RAW264.7) and more studies using different types of other immune cell lines or tissue-specific cell lines and further study in vivo and clinical investigations may be required to fully assess its effect. Our study also focused solely on the MAPK signaling pathway to corroborate the anti-oxidative benefits. However, specific studies such as deletion of these MAPK pathways will confirm the reported results. Moreover, more research into signaling pathways is required to completely understand the molecular mechanism of anti-oxidative effect. Remarkably, the anti-oxidative effect of weak ARW at $\mathrm{pH} 8.5$ was comparable to that of ARW_9.5, suggesting that weak ARW can be consumed daily for health improvement. 


\section{Conclusions}

Taken together, this is a primary study to show that weak ARW with pH 8.5 has anti-oxidative effect in RAW 264.7 murine macrophage cells through inhibiting the MAPK signaling pathway. In particular, in comparison to ARW_9.5, we discovered that ARW_8.5 also had a positive mediation in the parameters such as cell survival, OS, antioxidant, intracellular $\mathrm{Ca}^{2+}$ levels, and expression of MAPK signaling pathway-related proteins. To our knowledge, this in vitro study may be the first to demonstrate that weak ARW with $\mathrm{pH}$ 8.5 has an anti-oxidative effect on the body. As a result, consuming weak ARW daily could be an effective method for preventing OS-related diseases. In addition, the therapeutic potential of weak ARW ( $\mathrm{pH}$ 8.5) may answer partly the earlier skepticism and debate over the safety and efficacy of the long-term consumption of ARW.

Author Contributions: Conceptualization, K.-J.L.; writing—original draft preparation, T.T.T.; writing review and editing, T.T.T., A.F. and J.B.; data curation, T.T.T., S.S., S.-H.G. and M.H.R.; visualization, C.-S.K.; supervision, K.-J.L., S.-S.K. and W.-R.K. All authors have read and agreed to the published version of the manuscript.

Funding: This research received no external funding.

Institutional Review Board Statement: Not applicable.

Informed Consent Statement: Not applicable.

Data Availability Statement: All the data are contained within the article.

Acknowledgments: This study was supported by Hanumul Co., Ltd. (Goyang-si, Korea). The authors would like to thank Editage (Cactus Communications Korea Ltd., Seoul, South Korea) for language editing.

Conflicts of Interest: The authors declare no conflict of interest.

\section{References}

1. Tanaka, Y.; Saihara, Y.; Izumotani, K.; Nakamura, H. Daily ingestion of alkaline electrolyzed water containing hydrogen influences human health, including gastrointestinal symptoms. Med. Gas Res. 2018, 8, 160-166. [CrossRef]

2. Qian, L.; Shen, J.; Sun, X. Methods of hydrogen application. In Hydrogen Molecular Biology and Medicine; Sun, X., Ohta, S., Nakao, A., Eds.; Springer: Dordrecht, The Netherlands, 2015; pp. 99-107.

3. Park, S.K.; Qi, X.F.; Song, S.B.; Kim, D.H.; Teng, Y.C.; Yoon, Y.S.; Kim, K.Y.; Li, J.H.; Jin, D.; Lee, K.J. Electrolyzed-reduced water inhibits acute ethanol-induced hangovers in sprague-dawley rats. BioMed. Res. 2009, 30, 263-269. [CrossRef]

4. Jéquier, E.; Constant, F. Water as an essential nutrient: The physiological basis of hydration. Eur. J. Clin. Nutr. 2010, 64, 115-123. [CrossRef] [PubMed]

5. Johnson, E.C.; Adams, W.M. Water intake, body water regulation and health. Nutrients 2020, 12, 702. [CrossRef]

6. Islam, R.; Faysal, S.M.; Amin, R.; Juliana, F.M.; Islam, M.J.; Alam, J.; Hossain, M.N.; Asaduzzaman, M. Assessment of ph and total dissolved substances (tds) in the commercially available bottled drinking water. IOSR J. Nurs. Health Sci. 2017, 6, 35-40. [CrossRef]

7. Yang, E.J.; Kim, J.R.; Ryang, Y.S.; Kim, D.H.; Deung, Y.K.; Park, S.K.; Lee, K.J. A clinical trial of orally administered alkaline reduced water. Biomed. Sci. Lett. 2007, 13, 83-89.

8. Magro, M.; Corain, L.; Ferro, S.; Baratella, D.; Bonaiuto, E.; Terzo, M.; Corraducci, V.; Salmaso, L.; Vianello, F. Alkaline water and longevity: A murine study. Evid. Based Complement Alternat. Med. 2016, 2016, 3084126. [CrossRef]

9. Hanaoka, K. Antioxidant effects of reduced water produced by electrolysis of sodium chloride solutions. J. Appl. Electrochem. 2001, 31, 1307-1313. [CrossRef]

10. Naito, Y.; Takagi, T.; Uchiyama, K.; Tomatsuri, N.; Matsuyama, K.; Fujii, T.; Yagi, N.; Yoshida, N.; Yoshikawa, T. Chronic administration with electrolyzed alkaline water inhibits aspirin-induced gastric mucosal injury in rats through the inhibition of tumor necrosis factor- $\alpha$ expression. J. Clin. Biochem. Nutr. 2002, 32, 69-81. [CrossRef]

11. Jin, D.; Ryu, S.H.; Kim, H.W.; Yang, E.J.; Lim, S.J.; Ryang, Y.S.; Chung, C.H.; Park, S.K.; Lee, K.J. Anti-diabetic effect of alkaline-reduced water on oletf rats. Biosci. Biotech. Bioch. 2006, 70, 31-37. [CrossRef]

12. Logozzi, M.; Mizzoni, D.; Di Raimo, R.; Andreotti, M.; Macchia, D.; Spada, M.; Fais, S. In vivo antiaging effects of alkaline water supplementation. J. Enzyme Inhib. Med. Chem. 2020, 35, 657-664. [CrossRef]

13. Choi, Y.A.; Lee, D.H.; Cho, D.Y.; Lee, Y.J. Outcomes assessment of sustainable and innovatively simple lifestyle modification at the workplace-drinking electrolyzed-reduced water (oasis-erw): A randomized, double-blind, placebo-controlled trial. Antioxidants 2020, 9, 564. [CrossRef] 
14. Pizzino, G.; Irrera, N.; Cucinotta, M.; Pallio, G.; Mannino, F.; Arcoraci, V.; Squadrito, F.; Altavilla, D.; Bitto, A. Oxidative stress: Harms and benefits for human health. Oxidative Med. Cell. Longev. 2017, 2017, 8416763. [CrossRef]

15. Seo, D.W.; Yi, Y.J.; Lee, M.S.; Yun, B.S.; Lee, S.M. Differential modulation of lipopolysaccharide-induced inflammatory cytokine production by and antioxidant activity of fomentariol in raw264.7 cells. Mycobiology 2015, 43, 450-457. [CrossRef]

16. Nakao, N.; Kurokawa, T.; Nonami, T.; Tumurkhuu, G.; Koide, N.; Yokochi, T. Hydrogen peroxide induces the production of tumor necrosis factor-alpha in raw 264.7 macrophage cells via activation of p38 and stress-activated protein kinase. Innate. Immun. 2008, 14, 190-196. [CrossRef]

17. Taciak, B.; Białasek, M.; Braniewska, A.; Sas, Z.; Sawicka, P.; Kiraga, Ł.; Rygiel, T.; Król, M. Evaluation of phenotypic and functional stability of raw 264.7 cell line through serial passages. PLoS ONE 2018, 13, e0198943. [CrossRef]

18. Berghaus, L.J.; Moore, J.N.; Hurley, D.J.; Vandenplas, M.L.; Fortes, B.P.; Wolfert, M.A.; Boons, G.-J. Innate immune responses of primary murine macrophage-lineage cells and raw 264.7 cells to ligands of toll-like receptors 2, 3, and 4. Comp. Immunol. Microbiol. Infect. Dis. 2010, 33, 443-454. [CrossRef]

19. Chamberlain, L.M.; Godek, M.L.; Gonzalez-Juarrero, M.; Grainger, D.W. Phenotypic non-equivalence of murine (monocyte-) macrophage cells in biomaterial and inflammatory models. J. Biomed. Mater. Res. A 2009, 88, 858-871. [CrossRef]

20. Bardaweel, S.K.; Gul, M.; Alzweiri, M.; Ishaqat, A.; HA, A.L.; Bashatwah, R.M. Reactive oxygen species: The dual role in physiological and pathological conditions of the human body. Eurasian J. Med. 2018, 50, 193-201. [CrossRef]

21. Bustos, M.C.; Vignola, M.B.; Paesani, C.; León, A.E. Berry fruits-enriched pasta: Effect of processing and in vitro digestion on phenolics and its antioxidant activity, bioaccessibility and potential bioavailability. Int. J. Food Sci. Technol. 2020, 55, 2104-2112. [CrossRef]

22. Yang, M.; Dong, Y.; He, Q.; Zhu, P.; Zhuang, Q.; Shen, J.; Zhang, X.; Zhao, M. Hydrogen: A novel option in human disease treatment. Oxidative Med. Cell. Longev. 2020, 2020, 8384742. [CrossRef]

23. Asada, R.; Tazawa, K.; Sato, S.; Miwa, N. Effects of hydrogen-rich water prepared by alternating-current-electrolysis on antioxidant activity, DNA oxidative injuries, and diabetes-related markers. Med. Gas Res. 2020, 10, 114-121. [CrossRef] [PubMed]

24. Martinez, F.O.; Sica, A.; Mantovani, A.; Locati, M. Macrophage activation and polarization. Front. Biosci. 2008, $13,453-461$. [CrossRef]

25. Hirayama, D.; Iida, T.; Nakase, H. The phagocytic function of macrophage-enforcing innate immunity and tissue homeostasis. Int. J. Mol. Sci. 2018, 19, 92. [CrossRef] [PubMed]

26. Wynn, T.A.; Chawla, A.; Pollard, J.W. Macrophage biology in development, homeostasis and disease. Nature 2013, 496, 445-455. [CrossRef] [PubMed]

27. Gordon, S. The macrophage. Bioessays 1995, 17, 977-986. [CrossRef]

28. Gordon, S. The macrophage: Past, present and future. Eur. J. Immunol. 2007, 37, S9-S17. [CrossRef]

29. Forman, H.J.; Torres, M. Redox signaling in macrophages. Mol. Asp. Med. 2001, 22, 189-216. [CrossRef]

30. Juan, C.A.; de la Lastra, J.M.P.; Plou, F.J.; Perez-Lebena, E. The chemistry of reactive oxygen species (ros) revisited: Outlining their role in biological macromolecules (DNA, lipids and proteins) and induced pathologies. Int. J. Mol. Sci. 2021, 22, 4642. [CrossRef]

31. Zhao, J. Interplay among nitric oxide and reactive oxygen species: A complex network determining cell survival or death. Plant Signal. Behav. 2007, 2, 544-547. [CrossRef]

32. Ighodaro, O.M.; Akinloye, O.A. First line defence antioxidants-superoxide dismutase (sod), catalase (cat) and glutathione peroxidase (gpx): Their fundamental role in the entire antioxidant defence grid. Alex. J. Med. 2018, 54, 287-293. [CrossRef]

33. Begum, R.; Kim, C.S.; Fadriquela, A.; Bajgai, J.; Jing, X.Y.; Kim, D.H.; Kim, S.K.; Lee, K.J. Molecular hydrogen protects against oxidative stress-induced raw 264.7 macrophage cells through the activation of nrf2 and inhibition of mapk signaling pathway. Mol. Cell Toxicol. 2020, 16, 103-118. [CrossRef]

34. Kinjo, T.G.; Schnetkamp, P.P. Ca ${ }^{2+}$ Chemistry, Storage and Transport in Biologic Systems: An Overview. Madame Curie Bioscience Database. Available online: https:/ / www.ncbi.nlm.nih.gov/books/NBK5959/ (accessed on 1 September 2021).

35. Peng, T.I.; Jou, M.J. Oxidative stress caused by mitochondrial calcium overload. Ann. N. Y. Acad. Sci. 2010, 1201, 183-188. [CrossRef] [PubMed]

36. White, C.D.; Sacks, D.B. Regulation of map kinase signaling by calcium. In Map Kinase Signaling Protocols: Methods in Molecular Biology (Methods and Protocols); Seger, R., Ed.; Humana Press: Totowa, NJ, USA, 2010; Volume 661, pp. 151-165.

37. Zhang, W.; Liu, H.T. Mapk signal pathways in the regulation of cell proliferation in mammalian cells. Cell Res. 2002, 12, 9-18. [CrossRef]

38. Ichihara, M.; Sobue, S.; Ito, M.; Ito, M.; Hirayama, M.; Ohno, K. Beneficial biological effects and the underlying mechanisms of molecular hydrogen-Comprehensive review of 321 original articles. Med. Gas. Res. 2015, 5, 1-21. [CrossRef] [PubMed]

39. Nishimaki, K.; Asada, T.; Ohsawa, I.; Nakajima, E.; Ikejima, C.; Yokota, T.; Kamimura, N.; Ohta, S. Effects of molecular hydrogen assessed by an animal model and a randomized clinical study on mild cognitive impairment. Curr. Alzheimer Res. 2018, 15, 482-492. [CrossRef] [PubMed]

40. Pérez-Hernández, E.G.; Pedraza-Chaverrí, J. Antioxidant properties of electrolyzed reduced water and hydrogen. Vertientes Rev. Espec. Cienc. Salud 2011, 14, 5-13.

41. Kim, M.J. Strong Reduction Potential of Alkaline Electrolyzed (eo) Water for Preventing Oxidative Damage and Its Antibrowning, Antioxidation, and Anticancer Effects. Ph.D. Thesis, University of Georgia, Athens, GA, USA, 2010. 